\title{
Karel Werner (12 January 1925-26 November 2019)
}

\author{
DERMOT KILLINGLEY \\ Newcastle University \\ NE1 7RU \\ d.h.killingley@ncl.ac.uk

\section{ANNA KING} \\ University of Winchester \\ SO22 4NR \\ anna.king@winchester.ac.uk
}

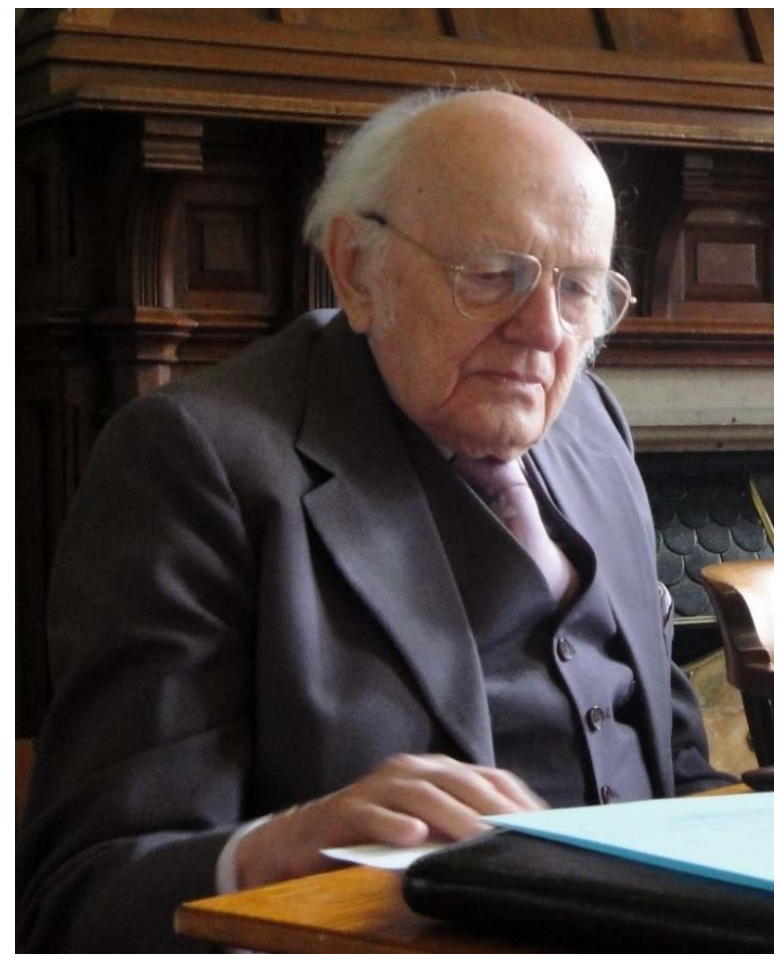

(c) Equinox Publishing Ltd 2021, Office 415, The Workstation, 15 Paternoster Row, Sheffield S1 2BX.

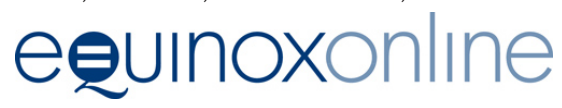


Professor Karel Werner's death was a particularly sad and momentous event for the editors of RoSA, because the journal is itself a development of the Spalding Symposium on Indian Religions which he founded in 1975. The Spalding Symposium came into being at a time when there were few scholarly platforms for researchers in South Asian religions, when education was expanding and when many university departments of theology and religious studies were creating lectureships in Indian religions. The first Symposia were informal meetings. Karel described simply tapping colleagues on the shoulder and persuading them into giving a paper. The series became the Spalding Symposium when Karel obtained funding from the Spalding Trust, founded in the 1920s to promote understanding of the religions of the world, which also supported his post in Durham University. Speakers at the early Symposia included Ninian Smart, Richard Gombrich, Daniel Mariau, Julius Lipner, Gavin Flood, John Brockington, Ian Harris, Eleanor Nesbitt, David Smith, Johannes Bronkhorst, Ian Whicher, Theodore Gabriel, Cathy Cantwell, Valerie Roebuck, Jackie Suthren Hirst, Peggy Morgan, and Lance Cousins. In fact the programmes read like a rollcall of entire generations of scholars engaged in research in Indian religions.

Karel organized the first Symposium in Selwyn College, Cambridge in March 1975, after chairing the Indian section of the 13th International Association for the History of Religions congress at Lancaster. The conference then moved peripatetically to London, Durham, Oxford, and Manchester. The sixth Symposium was held at the Cherwell Centre in North Oxford, where it remained for some years. Many participants remember the Cherwell Centre with nostalgia, partly because the Symposium always took place in April when the magnolia trees were in full flower. The meetings exuded conviviality, collegiality and good cheer, and included not only excursions to Blackwell's bookshop but trips to the pub where debates and discussions continued late into the night. In 2014 the Symposium resumed its original peripatetic habit, being held in various places where Indian religions are studied; but wherever it goes, the local organisers contribute their knowledge of local pubs. In 1982 Karel announced his intention of handing over the running of the Symposium, but it took two years to find a replacement-a measure of his value as an organizer. Eventually Peter Connolly took over, followed by Anna King, with the help of a committee-something that Karel, with his memories of communist bureaucracy, abominated. Anna was followed by Naomi Appleton, from 2014 to 2020.

The pattern of a weekend in April, starting on Friday evening and finishing at midday on Sunday, has continued. Another feature that has continued is that each paper, with the discussion following it, is allotted an hour or more in the timetable, a far more generous allocation than in many conferences, with shorter slots for research students. Saturday evening was, and still is, the time for a slide show illustrating the visual aspects of Indian traditions. Karel did not invite professional scholars exclusively, and all, whether

(c) Equinox Publishing Ltd 2021.

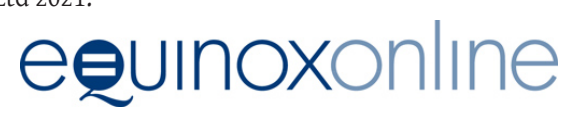


professional or not, were allowed to air individual or, as the case might be, eccentric ideas. Many were people for whom Indian religious traditions were, as they were for Karel, not merely historical objects but sources of enlightenment and spiritual nourishment. In this connection we may recall that it was Karel who campaigned for what was the British Association for the History of Religions to change its name to British Association for the Study of Religions. In the last few decades the pressures of research assessment-another bureaucratic device that Karel disapproved of-have changed the character of the papers somewhat, but have not suppressed the informality and free spirit of the Symposium.

Karel continued to take a great interest in the Symposium long after he had relinquished the role of convenor. The 35th Symposium, in 2010, was held in honour of his 85th birthday, and he returned to select the speakers. He invited many of the now distinguished scholars who had spoken at the early Symposia ('the old guard' or 'old chums' as he called them) to present papers. He also returned to his old custom of chairing every paper, rather than choosing a different person to chair each. On that occasion, Professor Julius Lipner, a Trustee of the Spalding Trust, praised the Spalding Symposium as 'the premier forum for regular scholarly interchange on Indological research, with special reference to Hinduism, Buddhism, Sikhism and Jainism', noting that 'presentations at the Symposium have resulted in a stream of publications...which has immeasurably enriched the domain of Indological research not only in the UK but also internationally'.

Karel introduced the practice of giving each year's Symposium a theme. He also started to gather the papers into collections, urging each author to spruce up his or her work for publication. The first of these collections was edited by Peter Connolly, as Perspectives on Indian Religions: Papers in Honour of Karel Werner (Delhi: Sri Satguru Publications, 1986); but three were edited by Karel himself: The Yogi and the Mystic: Studies in Indian and Comparative Mysticism (London, Curzon Press, 1989); Symbols in Art and Religion: The Indian and the Comparative Perspectives (London: Curzon Press, 1990); Love Divine: Studies in Bhakti and Devotional Mysticism (London: Curzon Press, 1993). These were published as Durham Indological Series, Nos. 1, 2 and 3, though Durham University gave them no support. The collected volumes continued, without the series title, with Indian Insights: Buddhism, Brahmanism and Bhakti: Papers from the Annual Spalding Symposium on Indian Religions, edited by Peter Connolly and Sue Hamilton (London: Luzac Oriental, 1997); and Indian Religions: Renaissance and Renewal, edited by Anna S. King (London: Equinox, 2007).

To provide a more regular outlet for such research, Anna King, who was then convenor, decided a journal was needed. On her initiative, and with Karel's advice and practical help, as well as that of Janet Joyce, the director of the publisher Equinox, Religions of South Asia (RoSA) was launched in 2007, partly but by no means exclusively publishing articles based on papers given at the Symposia. Its present editors, who are all Spalding regulars, often

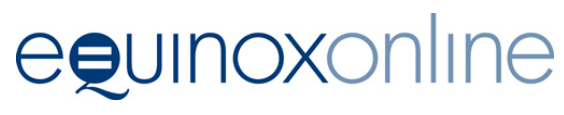


actively encourage, or where appropriate urge, the authors of such papers to write them up for RoSA, after which they are subject to the same rigorous anonymous peer review as all other submissions. RoSA continues to respect Karel's research interests, publishing papers by internationally respected scholars and younger academics, and sponsoring the latest research on distinctively South Asian or Indic religions-religions which continue to influence the patterns of thought and ways of life of millions of people. True to Karel's comparative perspective, we particularly welcome papers that discuss the confluence of religious cultures, and inter-cultural encounters.

Karel's research and publications spanned yoga, the Vedas and Upanișads, particularly aspects of these which contain philosophical ideas or can be construed as anticipating the beginnings of yoga; experiences, practices and concepts across Indian religions and philosophies, especially the nature of the transmigrating personality; and in Buddhism: ritual, devotion, ethics, concepts of rebirth and liberation, and art and symbols. As shown by his extensive bibliography, to be published in Buddhist Studies Review 37.1, which is primarily in English but also Czech, his great passion was for comparative religion and philosophy.

In a memoir he wrote for the 2010 Symposium, ${ }^{1}$ he tells us that he was born in 1925 in Jemnice, a small town in South Moravia, Czechoslovakia (now Czech Republic), but his family later moved to Znojmo, 40km to the east. He was raised as a Roman Catholic, and in 1934-1937 he was a server in the Dominican monastery in Znojmo and a member of the Legio Angelica, and in 1936, when he entered secondary school (gymnasium), he intended to enter the priesthood. In 1938, when the Sudetenland-the partly Germanspeaking borderland of Czechoslovakia-was annexed by Germany following the Munich agreement, the family moved again to Brno, also in South Moravia, where Karel continued his studies even after the German occupation of the whole country and the outbreak of war (1939). Around this time he abandoned the Church. His elder brother inclined him towards Marxism, but after reading the Czech nationalist Tomáš Garrigue Masaryk, he became an opponent of communism. During this period, he began his interest in Asian religions, and decided to study philosophy and comparative religion, not only academically but as a means to understand the nature and purpose of existence. As his studies developed throughout his career, they remained a matter of personal concern, not only as an isolated quest but as part of a struggle against established authority, whether ecclesiastical, Nazi or communist, or even that of a British university. He was concerned especially with Buddhism, yoga and mysticism. Without committing himself to any school of Buddhism, he found the teachings of the Buddha as recorded in the Pali texts

1. Some additional information is from https://en.wikipedia.org/wiki/Karel_Werner (accessed 10 June, 2020). 
to be rational and practical; and without following any modern yoga guru, he found the physical and meditative practices of yoga to be beneficial.

His education was restricted by the war, and his final examination, due in 1944, could not take place. He was drafted to work in a munitions factory, but by faking a stomach ulcer, and by his proficiency in German, he got himself assigned to an office job. When the war in Europe ended in May 1945, a refresher course was opened for students who had missed their exams. Karel passed them after five months, and embarked on a four-year course in philosophy and history in the Masaryk University in Brno. Simultaneously, he studied Sanskrit, which was taught there as a part of Indo-European comparative philology, and privately studied Chinese. He was appointed Assistant Lecturer in Sanskrit and Indian Civilization at the University of Olomouc (1947-1949); after gaining his doctorate, he continued as Lecturer (1949-1951).

In February 1948, the communist takeover led to purges of staff in ideologically sensitive subjects. Karel was branded a reactionary, and was refused appointment in Prague University. He was forced into manual jobs, including coal mines, gas works and tram driving (1951-1967). During those wilderness years he continued his interest in yoga. He mastered the basic postures and procedures of hatha yoga, practised Buddhist meditation, and corresponded with Buddhist and Yoga organizations abroad. As he later told Peter Harvey, he found Buddhist insight meditation most helpful and deepest when he was interrogated by the secret police, as a result of his contacts with foreign intellectuals. He circulated typescript copies of his translations of works on the subject, including the Dhammapada.

Karel's work on yoga became less clandestine when he discovered that members of the Soviet Academy of Sciences in its Moscow headquarters were practising hatha yoga postures as obligatory morning exercises. He used this information to persuade a newspaper to publish his first illustrated article on hatha yoga. As a result, he was invited to give lectures in Bratislava in 1963, and a year later he was allowed to repeat them in Brno and other towns. The social club of the biggest factory in Brno then invited him to conduct courses in hatha yoga, and enabled him to found a Yoga Club (1964), ostensibly to promote physical and mental health, in which he was able to introduce cautiously some spiritual elements, such as meditation, under the heading of relaxation. These courses clearly demonstrated the therapeutic effects of hatha yoga practice, and he was invited to lecture on 'Oriental therapies' in training courses for psychiatrists. He worked in the Psychiatric Institute in Kromeřríz (1967-1968), where he was engaged in a project researching the physiological processes that occur during the practice of yoga and meditation, and the possibilities of their therapeutic application. When the communist grip relaxed to some extent, he was given a post as research officer in Oriental therapy in the Psychiatric Institute, Kroměřǐž (1967-1968). During the Prague Spring of 1968, he applied for reinstatement in the University,

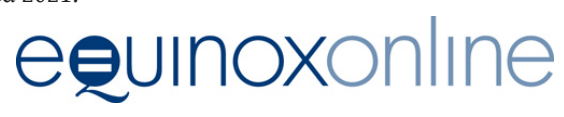


which was refused. Karel remarked that not even under Alexander Dubček's regime of 'communism with a human face' could a non-communist teach ideologically sensitive subjects.

After the Soviet invasion of Czechoslovakia (21 August, 1968), Karel emigrated to England. After a spell as a library assistant in Cambridge University Library and as a supervisor in Sanskrit in Churchill College, he was appointed Spalding Lecturer in Indian Philosophy and Religion in the School of Oriental Studies, University of Durham (1969-1990). Though there was no opportunity in Durham for comparative philosophy, which he considered his main interest, he was free to shape his courses, apart from an obligatory general course in Indian Civilization. He based the honours course in Sanskrit on religious and philosophical texts, with an option of the history of Hinduism and Buddhism for joint honours. This proved attractive to students at the time. Higher education was expanding, and there was great interest in Indian religions and philosophy, which inspired him to start the annual Symposia. Adult education was also flourishing at the time, and Karel gave lectures and seminars on Indian religions in the Durham County Residential College for Adult Education, and the Leeds University Adult Education Centre in Middlesbrough. For five years he taught a course on 'Indian Philosophy and Yoga' for the Durham University Extramural Department in Peterlee, which included hatha yoga tuition.

Karel wrote of the invigorating sense of freedom he felt after the claustrophobic experience of life behind the Iron Curtain. Participation in international conferences, sabbatical leaves and guest professorships in India and Sri Lanka (Peradeniya University in Kandy, Karnataka State University in Dharwar, University of Poona, and Benares Hindu University, 1975-1976), and vacation travel to other Asian countries in which Buddhism had found a footing, were 'previously undreamt-of experiences'. But his pleasant 21 years in Durham ended painfully. The university's measures to save money resulted eventually in the abolition of the Durham School of Oriental Studies. He was pressured to take early retirement with financial inducements, which he initially refused, but the intake of undergraduates was stopped, and he had only a couple of postgraduates to finish supervising. However, the free time enabled him to take a few assignments as guest lecturer for Swan Hellenic artistic tours to India, Nepal, Vietnam and Cambodia.

Karel's retirement coincided with the collapse of communism in Europe, and he was recruited to help in academic work in his native country, first as a corresponding member of the Czechoslovak Academy of Sciences and Arts (1991-1993) and then as a co-founder of the Department of the Study of Religions in the Masaryk University in Brno, for which he designed courses on Oriental religions, and where he was a visiting professor (1993-1998). Appointment as an honorary professorial research associate in the Department of the Study of Religions, SOAS, University of London, facilitated his work in preparing several books on Asian religious traditions in Czech-having previously

(c) Equinox Publishing Ltd 2021.

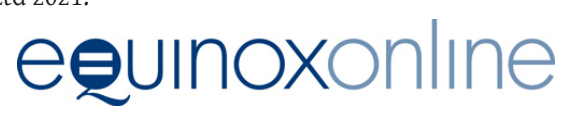


published his academic work in English, and occasionally German. Retirement further enabled him to continue his research work, to participate actively (under a Spalding grant) in the 2005 IAHR conference in Tōkyo, and to make his comeback to the 2010 Spalding Symposium, decribed above.

Karel Werner died peacefully at the age of 94 . His funeral service was held according to Buddhist rites, on December 9th, 2019, at the New Southgate Crematorium, London, and attended by many friends and colleagues. In his eulogy Professor Lipner said: 'The world of scholarship, and Karel's friends and acquaintances, will miss him sorely. But his memory and his work will live on, together with an abiding sense of appreciation for his wonderful contributions in his fields of learning.' On his personal qualities, he said: 'Karel carried his tall frame with a kindly smile and an air of dignity, but he was far from overbearing. He had a dry sense of humour, and was able to enter into the spirit of things with considerable aplomb.' An obituary appeared in The Times, Saturday, 8 February, 2020, p. 81, and 'Karel Werner: An Exemplary Life' by Alan Levy appeared in The Prague Post, 8-14 September, 1999, p. B2.

Karel Werner made a unique contribution to the teaching and understanding of Indian religions, and his combination of physical and intellectual energy impressed all who met him. Many colleagues are grateful for his support in developing their research and professional lives as scholars, but also comment appreciatively on his personal qualities as well as his contribution to scholarship. In the tribute written for the 35th Spalding Symposium celebrating Karel's 85th birthday, Professor David Smith praised his thought and writings as 'elegant, sharp, discriminating and insightful'. Dermot Killingley wrote that when he taught in Newcastle he was fortunate in having Karel as a colleague, sixteen miles to the south in Durham, whose interests in yoga and mysticism complemented his own in Sanskrit texts and their modern interpretation. Professor Peter Harvey recalled Karel's kindness and helpfulness to him as a young scholar, publishing papers that Peter had given at the symposia in his edited collections, and encouraging Curzon Press to publish a version of his $1981 \mathrm{PhD}$ thesis which came out in 1995 as The Selfless Mind: Personality, Consciousness and Nirvana in Early Buddhism. In his forthcoming obituary for Buddhist Studies Review, Peter recalls meeting Karel in the early 1970s at meetings organised by the late Lance Cousins, a leading scholar in the field of Buddhist Studies, and observes that Karel spoke there each year and was one of the most impressive and inspiring speakers, 'helping to spark my developing interest in Buddhism'.

Karel had a keen sense of humour, and was a masterful raconteur, and a gracious and hospitable host. He travelled widely, and he happily and enthusiastically engaged in vigorous debate on a range of subjects-politics, art, philosophy and ethics. He was not frightened of being perceived as eccentric, and Anna King's first physical encounter with him was as his guest at a Christmas lunch in SOAS at which he discoursed on Buddhist concepts of transmigration and karma while wearing reindeer antlers, eating Christmas pudding,

(c) Equinox Publishing Ltd 2021.

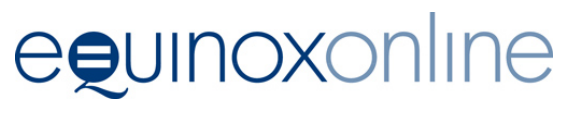


and pulling crackers. In all his activities he was supported by his wife Marian, to whom he was devoted. She is now the guardian of his literary legacy, and is collating papers for a detailed biography. At the 2010 Symposium she read a poem that she had written for him, a piece of 'McGonagallesque doggerel', as she called it, but a wonderful testimony of enduring love. 